UDC 81'37

DOI https://doi.org/10.24919/2308-4863/40-3-18

\author{
Roman SYTNIAK, \\ orcid.org/0000-0002-2630-3195 \\ PhD in Philology, \\ Associate Professor at the Department of Germanic Philology \\ Horlivka Institute for Foreign Languages \\ of the Donbas State Pedagogical University \\ (Bakhmut, Donetsk region, Ukraine) sytniakromannest@gmail.com
}

\title{
ETYMOLOGY AS A BASIS OF DIACHRONIC RESEARCH OF LEXICAL MEANING (LINGVO-HISTORIOGRAPHIC ASPECT)
}

The scientific study of the lexical meaning of words, the most variable, unstable form, has always been the most difficult task for linguists. A person simply cannot be satisfied with the number of meanings available. Integration of some societies into others, a great desire to meet the requirements of modern world (at different stages of history), technological innovations that require rethinking of terminology, extremely active international activities with their unquestionable demand for mutual understanding for economic prosperity, the simple reluctance of new generations to think in old frames become a pushing force for rethinking and reusing already existing lexical signs with a new connotation and denotation content.

The idea of studying words deep into history has always occupied an important place in linguistics. Due to technical progress (photo, audio and video equipment) etymological research in the last century has undergone significant scientific activation and popularization. Linguistic facts no longer had to be, (even difficult and a little funny to imagine), drawn or written with a pencil, or memorized and then the scientific community had to be persuaded to take the researcher at his word. Because of this, the large hypothetical nature of conclusions in many cases did not allow to obtain scientifically substantiated results. Now the evidence could be seen and heard exactly as it is.

Etymology is probably the most useful linguistic discipline for semantics, gathering such complete information about the meaning of a word and combining modern data, historical writings, pre-written reconstruction, and semantic typology for its research. Ignoring the help of etymology in the reconstruction of the semantic meaning of the word will inevitably result in a lack of material to explain certain speech phenomena, when trying to get help from other sciences. Of course, psychology, philosophy, culturology and other fields of knowledge make a great contribution to semasiological research, but without etymology a lot of results will acquire a certain artificiality and inconsistency.

Computerization of data processing, openness of research results of historical monuments and active cooperation of scientists due to the availability of constant contact (international summits, Internet conferences, etc.) increase the probability of obtaining new, more accurate scientific results of etymological research where several decades ago it was technically simply impossible.

Key words: semantic parallels, slice of time, historicism, semantic reconstruction, semantic field.

Роман СИТНЯК, orcid.org/0000-0002-2630-3195 кандидат філологічних наук, дочент кафедри германської філологіі Горлівського інституту іноземних мов Донбаського державного педагогічного університету (Бахмут, Донецька область, Україна) sytniakromannest@gmail.com

\section{ЕТИМОЛОГІЯ ЯК ПІДГРУНТЯ ДІАХРОННИХ ДОСЛІДЖЕНЬ ЛЕКСИЧНОГО ЗНАЧЕННЯ (ЛІНГВОІСТОРІОГРАФІЧНИЙ АСПЕКТ)}

Наукове дослідження лексичного значення слів - найбільш мінливої, нестабільної форми - завжди було найскладнішим завданням для лінгвістів. Людина просто не може задовольнятися наявною кількістю значень. Інтеграчія одних суспільств до інших, велике бажання відповідати вимогам сучасності (на різних етапах історії), технологічні інновації, щзо потребують переосмислення термінології, надзвичайна активна міжнародна діяльність з ї̈ безапеляційною вимогою взаєморозуміння заради економічного процвітання, просте небажання нових поколінь мислити старими категоріями стає беззаперечною рушійною силою переосмислення та «перевикористання» наявних лексичних знаків із новим конотаційним та денотаційним наповненням.

Ідея дослідження слів вглиб історії завжди займала поважне місие у мовознавстві. Завдяки технічному прогресу (фото-, аудіо- та відеоапаратурі) етимологічні дослідження у минулому столітті зазнали значної науко- 
вої активізації та популяризації. Мовні факти вже не треба було, навіть важко та трохи кумедно уявити, більше замальовувати чи записувати олівием або запам'ятовувати та переконувати наукову спільноту вірити досліднику на слово. Через изе велика гіпотетичність висновків часто не дозволяла отримувати науково підкріплені фактами результати. Тепер докази можна було побачити та почути саме такими, якими вони $\epsilon$.

Напевне, етимологія є найкориснішою лінгвістичною дисципліною для семантики, щуо збирає настільки повну інформацію про значення слова та поєднує заради своїх досліджень сучасні дані, історичні писемні пам'ятки, дописемну реконструкиію та семантичну типологію. Ігнорування допомоги етимології під час реконструкиї семантичного значення слова неодмінно буде мати наслідками недостатність матеріалу для пояснення певних мовленнсвих явищ за спроб отримати допомогу від інших наук. Звісно ж, психологія, філософія, культурологія та інші галузі знань роблять великий внесок у семасіологічні дослідження, але без етимологї багато результатів набуватимуть певної итучності та необтрунтованості.

Комп'ютеризачія обробки даних, відкритість результатів досліджень історичних пам'яток та активна кооперація вчених завдяки доступності постійного контакту (міжнародні саміти, інтернет-конферениії та ін.) у рази збільшують вірогідність отримання нових, більш точних наукових результатів етимологічних досліджень там, де шео кілька десятиліть тому ие було технічно просто неможливо.

Ключові слова: семантичні паралелі, зріз часу, історизм, семантична реконструкиія, семантичне поле.

Setting of the issue. Any attempt to investigate lexical meaning of words inevitably brings the linguists to the necessity of making time parallels within one language or far out of its boundaries. Etymology is a key to explanation of the development of meaning in the past, the state of the meaning in the present and even prospective of the future semantic evolution.

The most convenient for the etymologists seems to be the study of grammatical forms due to the sufficient number of available written memorabilia, due to the constancy, durability and actual clarity of the evidence to build a fairly clear diachronic chain.

Phonetics becomes more difficult to etymologize at the stage where it is possible to certify the sound of word forms with the help of "living" memory of native speakers, or recordings made by technical devices that began to gain more or less widespread access only in the twentieth century. Sound recording existed before, but was too complex to apply, in the "field" of research, as a result, was very occasional in research in linguistics and did not provide enough quantitative evidence to identify scientifically sound theories that would require a whole library, and made impossible the practical part of the implementation of the language experiment.

The disadvantage of diachronic study of the semantics of the word XIX - first half of the twentieth century was insufficient attention to its environment linguistic and extralinguistic factors, without which the study became more philosophical or scientifically unproven due to assumptions and a small number of examples. Due to the reluctance to combine linguistics with history, sociology, culturology, psychology and other sciences that could help reveal and explain the nature of lexical changes, and due to the extreme dynamism of the lexical system, language researchers did not pay enough attention to them, and sometimes simply ignored this aspect. The presence of such a problem was indicated by: R.O. Budagov (Будагов,
1963: 6), V.A. Zvegintsev (Звегинцев, 1962: 10), V.V. Vinogradov (Виноградов, 1994: 620), V.A. Grechko (Гречко, 2003: 117.)

Analysis of the research works and publications. One of the most important and influential works on the issue that are considered in the article are the works of the linguists that have analyzed the state of etymology and semasiology cooperation on different historical stages. They are the researchers that motivate new generations of linguist direct their interest to the historical investigation in the sphere of word meaning. The analyzed ideas are represented by R.O. Budagov, V.A. Zvegintsev, V.V. Vinogradov, V.A. Grechko, O.A. Merkulova, J.J. Warbot, O.M. Trubachov, A. Zaliznyak, R. Milehammer and some other influential European linguists.

The aim is to reveal the views of the prominent European linguists of the XIX - early XXI century on the importance of etymology for the studies of the lexical meanings of words, to identify the perspectives of cooperation of etymology and semasiology in modern linguistics.

The tasks to achieve this aim are:

1. To highlight the views of European researchers of the language of the XIX - early XXI century on the role of etymology in the studies of lexical meanings of words. 2. To outline new visions of cooperation of semasiology and etymology.

Main body. O.A. Merkulova in her article "Semantic laws and the image of the world" considers the problem of developing new methods of etymological analysis, which are based not only on phonetic laws but also on the semantics of words. She writes about the discovery of semantic laws by analyzing linguistic phenomena through the culturological aspect.

In her opinion, the results of etymological research have played a very important role in the formation of the comparative-historical method. Compared with the flourishing of etymology in the first half of the 
XIX century, at the present stage one can observe a fading of interest in etymology. Traditional methods, convinces O. A. Merkulova, do not correspond to the current state of theoretical linguistics because, paying great attention to phonetic laws, they do not take into account the semantic component of the word (Меркулова, 2008: 39).

A Well-known modern linguist J. J. Warbot admits that for all the indisputability of the connection of etymological analysis of the form and meaning of the word, the common opinion about the special difficulties of semantic analysis (explanation of the connection and development of meanings, reconstruction of primary motivation and primary meaning) has objective grounds, because semantic changes are extremely diverse in quality and range, and in semantics there are no laws that define mandatory (for certain conditions) changes in values. Thus, the etymology is based only on the probability of semantic changes.

But, she notes, in the analysis of the semantic aspect of the word etymology has a set of methods based on the principle of analogy: the method of semantic parallels, the method of semantic field (and derived principles of nomination), the method of comparison with the semantic meaning of the etymological nest.

The method of semantic parallels really works as cases of similar development (or combination) of values are used as proof of the expected change of value or possibility of combination of values.

The method of semantic field involves consideration of word development against the background of synonymous or semantically similar formations (names of relief, names of shoes, terminology of a certain craft, etc.), the material of which reveals typical for this field principles of nomination (primary motivation) and, accordingly, probable primary motivation of the studied word is determined. Thus, the well-known motivation of the names of the relief by the names of parts of the human or animal body (Ukr. ніс, хребет) allows to genetically identify the Russian cmenb - "forestless, grassy space" (but primary - "elevated plain") with dialectal cmen b - "horse's withers".

Semantic changes and types of motivation are only partially explained by the general laws of human thinking (hence the semantic parallels of changes such as close $\rightarrow$ soon, severity $\rightarrow$ sadness) or general experience of material production, social life, human communication (sharp $\rightarrow$ fast, strong $\rightarrow$ fast $\rightarrow$ bold, material $\rightarrow$ an object made of this material) (Варбот, 2002: 4).

Most of the changes in values are due to the natural and social environment, the history of culture, which are largely different for each nation. Therefore, when using the methods of semantic parallels and the semantic field, the etymology is based primarily on data from the same language or closely related languages. The greatest linguistic proximity of the compared materials is provided by the method of comparing the semantics of the analyzed word with the semantic meaning (values of all related tokens) of the etymological nest, which is determined by the source of this word.

The study of the meaning of a word through context and discourse has become one of the headstones of the diachronic approach, which, reproducing "living" situations made it possible to observe the existence and changes of lexical meaning of words in specific languages at specific time.

At the present stage of linguistics, etymological studies of semantics involve a large number of auxiliary sciences and disciplines that contribute to the completeness and scientific verification of the results.

J.J. Warbot insists that, “... etymological research should be based on a colossal basis of data not only from other areas of linguistics, but also a variety of fields of knowledge" (Варбот, 2002: 4).

The contribution of etymology to the study of the lexical meaning of a word is undoubtedly hard to overrate.

O.M. Trubachov was convinced that no linguistic discipline collects as complete information about the meaning of the word as etymology, which combines modern data, historical written monuments, pre-written reconstruction and semantic typology for the sake of his research. Misunderstanding or deliberate ignoring the help of etymology in the reconstruction of the semantic meaning of the word, he warns, will inevitably lead to a lack of material to explain certain speech phenomena, attempts to get help from other sciences. He called the importance of semantics for the etymologist the truth that does not require proof (Трубачёв, 1976: 64).

O.M. Trubachov sees the prospects of cooperation between etymology and semantics in diachronic research. "Unfortunately, this discipline, which is experiencing rapid development in our time, appears before us in a somewhat self-sufficient form. "The primacy of synchrony over diachrony" still outweighs the wiser breadth of views, although the reason is perhaps sometimes not a conscious tendency, but, apparently, a lack of awareness" (Трубачёв, 1976: 65).

Of course, these views were relevant to the 1970 s and 1980s. In modern linguistics, synchrony is beginning to be perceived as a component of diachrony (A. Zaliznyak 2001, O. S. Kubryakova 2009, 2012). If we perceive diachronic research as a vertical combination of synchronic research at different historical stages, then the problem of contrasting synchrony and diachrony will begin to decrease. 
The urgency of close cooperation of etymology with historical semantics is inexhaustible precisely because they are based on a common idea of historicism, changes in words of lexical meaning over time. The study of history always has and will have some error in the results due to the fact that controversial or unknown links are filled with several options, or built on logical parallels with the already proven facts.

The presence of many interpretations of the etymology of the same words J. J. Warbot notes is quite natural: "The etymological solution is largely based on scientific restoration, reconstruction of changes experienced by the word, and almost always is a hypothesis" (Варбот, 2002: 7). It is possible that when the unknown begins to frighten the researcher so much, science will stop.

As the etymologist goes deeper, following the comparative-historical method, believes J.J. Varbot, it is necessary to simply develop new and refine the old methods and approaches. "Etymology as a science justifies its purpose and develops due to strict adherence to the comparative-historical method, improving its techniques, expanding the information involved" (Варбот, 2002: 7).

Modern linguists like Y. Malkiel, A. Liberman are far from accepting the idea of the scientific interest fall towards etymological research. History of words is not going to stop feeding linguistics with new data.

A renowned modern German linguist, researcher of Germanic languages, specializing in prehistoric reconstruction, R. Milehammer gives his vision of what etymology is at the present stage of linguistics, which is within its interests and which key issues it focuses on. Each paragraph refers to the lexical meaning of words, graphic, phonetic and grammatical forms.

First, he believes, etymology is the foundation of historical linguistics, as it examines the chronological stages of word formation in the initial stages, and it is etymology that is responsible for establishing the changes that have taken place over a long historical development. Second, etymology is essentially a diachronic perspective of the relationship of one chronological stage of language with the previous one. Third, it is necessary to distinguish between lexical etymology and structural etymology, which have certain methodological branches. Fourth, the etymology should be divided into categories according to quality (accuracy of results). Theoretically, only one "correct" etymology of what is being studied is ideal. But, R. Milehammer is sure, the reconstruction of the chain of changes and the starting point in practice is a puzzle with many missing parts. Therefore, some etymologies are more likely than others. Fifth, the etymology does not have to be tied to one language. The etymology of one word should include the study of its history in another language, possibly in the third, fourth, if the word came into the language under study from another or other languages. R. Milehammer connects the sixth important characteristic of the etymology of the XXI century with its special methodological position, which contains a certain contact element, which is opposed to the so-called purely "internal" etymology. Contact etymology provides an opportunity to consider more linguistic and, especially, socio-historical circumstances. The researcher insists on the theoretical equivalence of both directions (Mailhammer, 2014: 423).

Conclusions. Due to new technologies and openness of international cooperation in term of linguistic science, etymology is and is going to be of a great help for investigations of lexical meaning of words.

Popularization of diachronic investigations does not mean decline in interest in etymological research but lead it to the new way of research work.

\section{BIBLIOGRAPHY}

1. Будагов Р.О. Сравнительно-семасиологические исследования (романские языки). Москва: МГУ, 1963. 302 с.

2. Варбот Ж.Ж. Историко-этимологический словарь современного русского языка. Москва, 2002. Т. 1. С. 4-7.

3. Виноградов В.В. История слов: около 1500 слов и выражений и более 5000 слов, с ними связанных. Москва: Толк, 1994. $1138 \mathrm{c}$.

4. Гречко В.А. Теория языкознания. Москва: Высшая школа, 2003. 375 с.

5. Зализняк А.А. Семантическая деривация в синхронии и диахронии: проект «Каталога семантических переходов». Вопросы языкознания. 2001. № 2. С. 13-25.

6. Звегинцев В.А. Проблема значения в современном зарубежном языкознании. Новое в лингвистике. 1962. № 2. С. 9-16.

7. Кубрякова Е.С. В поисках сущности языка: Когнитивные исследования / Ин-т. языкознания РАН. Москва: Знак, 2012. $208 \mathrm{c}$.

8. Меркулова О.А. Семантические законы и образ мира. Вестн. Воронеж. гос. ун-та. Сер. Лингвистика и межкультурная коммуникаичия. 2008. № 3. С. 39-43.

9. Трубачев О.Н. Этимологические исследования и лексическая семантика. Принщипь и методы семантических исследований. Москва: Наука, 1976. С. 148-173.

10. Liberman A. The State of English Etymology (A Few Personal Observations). Studies in the History of the English Language V., Berlin, New York, 2010. P. 161-185.

11. Mailhammer R. Etymology. The Routledge Handbook of Historical Linguistics. London, 2014. № 20. P. $423-442$.

12. Malkiel Y. Etymology. Cambridge: Cambridge University Press, 1993. 223 p. 


\section{REFERENCES}

1. Budagov R.O. Sravnitelno-semasiologicheskie issledovaniya (romanskie yazyiki). [Comparative-semasiological research (Romanic languages)]. Moskva: MGU, 1963. 302 s. [in Russian].

2. Varbot Zh.Zh. Istoriko-etimologicheskiy slovar sovremennogo russkogo yazyika. [Historical-etymological dictionary of the modern Russian language]. Moskva, 2002. T. 1. S. 4-7. [in Russian].

3. Vinogradov V.V. Istoriya slov: okolo 1500 slov i vyirazheniy i bolee 5000 slov, s nimi svyazannyih. [History of words: about 1500 words and phrases and more than 5000 words connected with them]. Moskva: Tolk, 1994. 1138 s. [in Russian].

4. Grechko V.A. Teoriya yazyikoznaniya. [Theory of Linguistics]. Moskva: Vyisshaya shkola, 2003. 375 s. [in Russian].

5. Zaliznyak A.A. Semanticheskaya derivatsiya v sinhronii i diahronii: proekt «Kataloga semanticheskih perehodov». [Semantic derivation in synchrony and diachrony: project "Catalogue of semantic shifts"]. Voprosyi yazyikoznaniya, 2001. № 2. S.13-25. [in Russian].

6. Zvegintsev V.A. Problema znacheniya v sovremennom zarubezhnom yazyikoznanii. [The problem of meaning in modern foreign linguistics]. Novoe v lingvistike, 1962. № 2. S. 9-16. [in Russian].

7. Kubryakova E.S. V poiskah suschnosti yazyika: Kognitivnyie issledovaniya. [Searching for the essence of the language]. In-t. yazyikoznaniya RAN. Moskva: Znak, 2012. 208 s. [in Russian].

8. Merkulova O.A. Semanticheskie zakonyi i obraz mira. [Semantic laws and the image of the world]. Vestn. Voronezh. gos. un-ta. Ser. Lingvistika i mezhkulturnaya kommunikatsiya, 2008. № 3. - S. 39-43. [in Russian].

9. Trubachyov O.N. Etimologicheskie issledovaniya i leksicheskaya semantika. Printsipyi i metodyi semanticheskih issledovaniy. [Etymological research and lexical semantics. Principles and methods of semantic research]. Moskva: Nauka, 1976. S. 148-173. [in Russian].

10. Liberman A. The State of English Etymology (A Few Personal Observations). Studies in the History of the English Language V., Berlin, New York, 2010. P. 161-185.

11. Mailhammer R. Etymology. The Routledge Handbook of Historical Linguistics, London, 2014. № 20. P. $423-442$.

12. Malkiel Y. Etymology. Cambridge: Cambridge University Press, 1993. 223 p. 